\title{
Investigation of Polyacrylic Acid Toxicity in Human Breast Cancer (MCF-7) and Mouse Fibroblast (L-929) Cell Lines
}

\author{
Melike Ersoz ${ }^{1^{*}}$, Adil Allahverdiyev ${ }^{2}$
}

\begin{abstract}
In recent years, biopolymers have been widely used in various fields of medicine. Before using any polymer, its biocompatibility should be examined. Polyacrylic acid (PAA), a polyelectrolyte, is known to be used as an adjuvant effect in immunology, anti-thrombogenic effect in medical experiments, and as a carrier in drug delivery systems. Although there are studies on various conjugates and nanoparticles of PAA, studies on its toxicity alone are limited. Determination of toxicity in biopolymer studies is extremely important. Cultures of various cells are used for toxicity analyses. This study aimed to investigate the toxicity of PAA in human breast cancer (MCF-7) and mouse fibroblast (L-929) cell lines by various methods. Cell culture, 3-(4,5-dimethyltriazol-2-yl)-2,5-diphenyltetrazolium bromide (MTT), trypan blue and 4,6-diamidino 2 phenylindole (DAPI) methods were used in the study. The half-maximal effective concentration $\left(\mathrm{EC}_{50}\right)$ value of PAA was $6.6 \mathrm{mg} / \mathrm{ml}$ in MCF 7 cells and 1.8 $\mathrm{mg} / \mathrm{ml}$ in L-929 cells. Apoptosis was observed in cells on the increasing PAA concentration with DAPI. With these results, the cytotoxic properties of PAA were determined in vitro. Accordingly, the biocompatibility of polymers to be used in modeling should be supported by in vitro and in vivo studies.
\end{abstract}

Keywords: Apoptosis, biocompatibility, cytotoxicity, polyacrylic acid.

${ }^{1}$ Department of Molecular Biology and Genetics, University of Demiroglu Bilim, Istanbul, Turkey.

${ }^{2}$ National Medival Research Institute of

Prevention by V.Akhundov, Baku, Azerbaijan.

* Corresponding author: Melike Ersoz

E-mail address: mersoz1@yahoo.com ORCID:0000-0002-5289-5809

Address: University of Demiroglu Bilim, Faculty of Arts and Sciences, Department of Molecular Biology and Genetics, Esentepe, Buyukdere St. No:120 34394, Sisli/Istanbul, Turkey.

Telephone number: +902122136488

DOI: 10.2478/ebtj-2021-0021

(C) 2021 Authors. This work was licensed under the Creative Commons Attribution-NonCommercialNoDerivs 4.0 License.

\section{Introduction}

Polyacrylic acid (PAA), an anionic polyelectrolyte, is a water-soluble $(1,2)$ and artificial biodegradable polymer used in drug release studies $(3,4)$. PAA has hydrogel property and hydrogels are frequently preferred a wide range of medicinal applications in terms of tissue compatibility with their physical properties similar to human tissues $(5,6)$. For a polymer to be used in medicine and biology, it must have biocompatibility properties. It is seen that anionic polyelectrolytes attract attention in studies related to biocompatibility. Biocompatible PAA is used as a polyelectrolyte in biomedical applications $(6,7)$ such as immunological studies (8), drug delivery $(9,10)$, and enzyme immobilization (11). In a study, PAA was shown to improve cellular uptake of encapsulated curcumin in breast cancer (12). PAA has been used as a biodegradable polymer in various nanoparticle studies $(13,14)$. In addition, PAA is a widely used polymer in ophthalmology and was used as a viscosity enhancer agent in combination with chitosan (15). In recent years, research has focused on developing new drug delivery systems containing nanogels based on PAA (16).

Cellular viability was performed by a standard MTT assay method to evaluate the biocompatibilities of PAA. Exposure with synthesized PAA at different concentrations ranging from 20 to $500 \mu \mathrm{g} / \mathrm{mL}$ for 24 hours shows negligible cytotoxicity in both MCF-7 and $3 \mathrm{~T} 3$ cells (17). Determining the toxicity of biopolymers is extremely important in various fields of medicine and biology. In vitro PAA toxicity has been determined by using cell lines in studies with various polymers, hydrogels, and copolymers in the literature. Various cell lines including human breast cancer MCF-7, fibroblast 3T3, HCT 116, MDA- 
MB-231 were used in this toxicity studies (17-19). In our current study, two types of cell lines were used for in vitro toxicity analysis. These are the MCF-7 and L-929 cell lines. The MCF-7 cell line originates from human adenocarcinoma and is used in vitro toxicity studies. This cell line is estrogen positive and non-invasive and grows as a monolayer. They are subcultured by a passage with trypsin-EDTA and It is cultivated at $37^{\circ} \mathrm{C}$ in a $5 \% \mathrm{CO}_{2}$ environment. L929 cells are the most widely used adherent mouse fibroblast cell line approved by ISO 10993-5 for cytotoxicity assessment of biomedical devices/materials prior to clinical trials. For this reason as another cell line, L-929 cells were preferred, which are widely used in biocompatibility studies, have metabolic and genetic stability, and have good reproducibility. Trypsin is used for subculture. It is cultivated and grows at $37^{\circ} \mathrm{C}$ in a $5 \% \mathrm{CO}_{2}$ environment $(17,20,21)$.

Apoptosis is a genetically controlled programmed cell death in which the damaged cells are eliminated without damaging other healthy cells. It has critical importance in proliferation and cell cycle in benign and malignant tumors. In apoptosis, intracellular or extracellular death signals, and cell death receptor or apoptotic mechanism via mitochondria activates, and as a result DNA fragmentation occurs. Apoptotic bodies are recognized and phagocytosed by macrophages (22). Apoptosis can be demonstrated in cell culture studies using the DAPI (4',6-diamidino-2-phenylindole) staining technique (23).

In order to any polymer to be applied in practice, its biocompatibility should be examined. Studies on the toxicity of PAA alone are limited in the literature. In this study, the toxic effects of different concentrations of PAA on MCF-7 and L-929 cell lines were determined using morphological, MTT, and trypan blue methods. Morphologically observed cell death in MCF-7 and L-929 cells treated with different concentrations of PAA was evaluated under a fluorescent microscope by staining DNA with a specific dye DAPI.

\section{Materials and Methods \\ MCF-7 and L-929 cell culture}

MCF-7 cells were obtained from the Istanbul Bilim University, Faculty of Medicine laboratory, and L-929 cells were obtained from the Ege University, Faculty of Engineering Bioengineering Department Laboratory. MCF-7 cells were cultured in a 1:1 ratio of DMEM-F12 medium (Sigma) containing 10\% Fetal Bovine Serum (FBS) (Seromed) at $37^{\circ} \mathrm{C}$ in an incubator containing $5 \% \mathrm{CO}_{2}$. L-929 cells were cultured in DMEM/HAM'S F12 (Biochrom) medium containing 1\% L-Glutamine (Biological Industries), 2x Penicillin Streptomycin (Biological Industries), $50 \mu \mathrm{g} / \mathrm{ml}$ Gentamicin (Biological Industries), 1\% HEPES, and $15 \% \mathrm{FBS}$ at $37^{\circ} \mathrm{C}$ in an incubator containing $5 \% \mathrm{CO}_{2}$.

\section{Preparation of PAA}

Commercially purchased 35\% g/ml PAA (Sigma-Aldrich, MA:100.000) was used in the experiments. A final concentration of $50 \mathrm{mg} / \mathrm{ml} \mathrm{PAA}$ ( $\mathrm{pH} 7.00$ ) was prepared in PBS. It was sterilized with a $0.45 \mu \mathrm{l}$ and $0.22 \mu$ filter. $25 \mathrm{mg} / \mathrm{ml}, 20 \mathrm{mg} / \mathrm{ml}$, $15 \mathrm{mg} / \mathrm{ml}, 10 \mathrm{mg} / \mathrm{ml}, 5 \mathrm{mg} / \mathrm{ml}, 4 \mathrm{mg} / \mathrm{ml}, 2 \mathrm{mg} / \mathrm{ml}, 1 \mathrm{mg} / \mathrm{ml}, 0.5$ $\mathrm{mg} / \mathrm{ml}, 0.1 \mathrm{mg} / \mathrm{ml}, 0.05 \mathrm{mg} / \mathrm{ml}, 0.005 \mathrm{mg} / \mathrm{ml}$ at concentrations PAA was applied to the cells for 24 hours.

\section{Determination of cell viability}

Cell viability is detected by counting cells under a microscope on a Thoma slide using trypan blue dye. Living cells are impermeable to the trypan blue dye. If the cell membrane is damaged for any reason, the cell is permeable the trypan blue dye and trypan blue stain the cytoplasm. In a microscopic examination, living cells appear bright and transparent, while dead cells are stained blue (24). $5 \times 10^{4}$ cells/ml MCF-7 and L-929 cells were seeded in each well of the 24 -well plates and incubated in the completed DMEM-F12 medium at $37{ }^{\circ} \mathrm{C}$ in a $5 \% \mathrm{CO}_{2}$ incubator. After incubation, different concentrations of PAA were added to the wells. The changes caused by PAA on cells at 24 hours were examined with an inverted microscope (Olympus). Cells were trypsinized and transferred to microtubes. An equal amount of cell suspension and trypan blue was added to a tube. Dye permeable and impermeable cells were counted on Thoma slides under a light microscope. The $\%$ viability was calculated using the formula. Viable cells $\%=$ (total number of viable cells per $\mathrm{ml}$ of aliquot/total number of cells per $\mathrm{ml}$ of aliquot $) \times 100$

\section{Investigation of cytotoxicity of PAA on MCF-7 and L-929 cells}

MTT is a drug susceptibility test that aims to indirectly assess cell growth and/or cell death. MTT is actively absorbed into cells and is a colored, water-insoluble formazan reduced by a mitochondrial reaction. Using the MTT method, living cells in a cell population can be determined quantitatively by the calorimetric method (25). MTT solution was prepared as 30 $\mu \mathrm{g}$ MTT/ $50 \mu \mathrm{l}$ medium and sterilized by filtering. MCF-7 and L-929 cells ( $1 \times 10^{4}$ cells $/ \mathrm{ml}$ for both) were seeded in 96-well microplates. The microplate was incubated at $37^{\circ} \mathrm{C}$ in a $5 \% \mathrm{CO}_{2}$ incubator for 48 hours. Then, PAA, whose toxic effect will be examined at different concentrations, was added to the wells. The microplate was incubated for 24 hours at $37^{\circ} \mathrm{C}$ in a $5 \% \mathrm{CO}_{2}$ incubator. $50 \mu$ of MTT was added to each well and incubated in the incubator for 4 hours. Formazan crystals were dissolved with DMSO and read at $570 \mathrm{~nm}$ by microplate ELISA. The effective dose $\left(\mathrm{EC}_{50}\right)$ that inhibited $50 \%$ of the cells was calculated with the results obtained with the formula Cell Viability \% $=(\mathrm{OD}$ value of treated cells / OD value of control cells $) \times 100$.

\section{Determination of apoptotic effect of PAA on MCF-7 and L-929 cells}

Mammalian cells undergo apoptosis to eliminate cellular damage. To observe cell death morphologically, cells are labeled with DAPI and examined under a fluorescent microscope (Olympus). DAPI forms a fluorescent complex with double-stranded DNA. Typical morphologies of apoptotic cell death are observed with DAPI labelings, such as chromatin condensation and apoptotic bodies containing nuclear fragments (23). MCF-7 and L-929 cells $\left(5 \times 10^{4}\right.$ cells $/ \mathrm{ml}$ for both) were seeded on coverslips. Different concentrations of PAA 
were added after culture. At the end of the incubation, the cells on the coverslips were fixed with methanol for 5 minutes at 20 ${ }^{\circ} \mathrm{C}$. The cells were incubated with DAPI $(0.1 \mu \mathrm{g} / \mathrm{ml}$ PBS $)$ for nuclear staining at room temperature, and in the dark for 15 minutes. DAPI was removed from the wells, and evaluated with a UV filter in a fluorescent microscope. At least 10 fields were randomly selected, and all cells in each field were counted. The percentage of apoptotic cells was determined by the equation ((number of apoptotic cells / total number of cells) x100).

\section{Statistical Analysis}

Data were calculated as the mean \pm standard error of the mean (SEM) of three separate experiments performed at least three times. Statistical analysis was performed using GraphPad Prism software version 6 (GraphPad Software, La Jolla, CA). Mann-Whitney nonparametric test was used for apoptosis analysis. Viability and $\mathrm{EC}_{50}$ values were calculated using GraphPad Prism. P values less than 0.05 were considered statistically significant.

\section{Results \\ Morphological effect of PAA at different concentra- tions on MCF-7 and L-929 cells}

Control MCF-7 cells non-treated with PAA showed characteristic morphological features. Concentrations of PAA between $25 \mathrm{mg} / \mathrm{ml}$ and $5 \mathrm{mg} / \mathrm{ml}$ caused deformation in MCF-7 cells. The morphological changes of the cells are as follows; loss of cell volume, absence of cell surface extensions, rounded cells, and reduced cell surface coverage. It was observed that the cells treated with PAA at concentrations between $0.5 \mathrm{mg} / \mathrm{ml}$ and $0.005 \mathrm{mg} / \mathrm{ml}$ were similar to the cells in the control group. When L-929 cells were examined microscopically, control cells had characteristic morphology. It was determined that the cells applied with PAA concentrations between $25 \mathrm{mg} / \mathrm{ml}$ and $5 \mathrm{mg} /$ $\mathrm{ml}$ had cell shrinkage, no surface extensions, and were round in shape and the surface coverage was reduced. Cells treated with PAA concentrations between $0.5 \mathrm{mg} / \mathrm{ml}$ and $0.005 \mathrm{mg} / \mathrm{ml}$ were observed to be similar to cells in the control group (Figure 1).

\section{The effects of PAA on the viability of MCF-7 and L-929 cells}

The effects of PAA on the viability of MCF-7 and L-929 cells were determined by trypan blue dye. Cells stained with trypan blue were considered dead cells, while cells not stained with trypan blue and appearing transparent and bright were considered viable cells. Trypan blue staining results showed that the number of viable cells decreased significantly in MCF-7 cells treated with $20 \mathrm{mg} / \mathrm{ml}$ PAA compared to control cells (P $<0.05$ ) (Figure 2A). The cells non-treated with PAA were not stained with trypan blue dye. The number of viable cells was significantly reduced in L-929 cells treated with $20 \mathrm{mg} / \mathrm{ml}$ and $10 \mathrm{mg} / \mathrm{ml}$ PAA compared to control cells $(\mathrm{P}<0.01$ and $\mathrm{P}<0.05$, respectively) (Figure $2 \mathrm{~B}$ ).

\section{Determination of the toxic effects of PAA on MCF-7}

\section{and L-929 cells by MTT method}

A large number of formazan crystals were observed in the control cells by the MTT method. The color change of formazan crystals dissolved with DMSO was measured in ELISA at a wavelength of $570 \mathrm{~nm}$. According to ELISA results, formazan crystals in MCF-7 cells decreased significantly at all concentrations of PAA between $10 \mathrm{mg} / \mathrm{ml}$ to $25 \mathrm{mg} / \mathrm{ml}$ compared to the control group $(\mathrm{P}<0.05)$. The $\mathrm{EC}_{50}$ value of PAA affecting $50 \%$ of MCF-7 cells was determined as $6.6 \mathrm{mg} / \mathrm{ml}$ (Figure 3A). Formazan crystals in L-929 cells treated with PAA increased with decreasing concentration of PAA. Compared to L-929 cells non-treated with PAA, formazan crystals in L-929 cells decreased significantly with $15 \mathrm{mg} / \mathrm{ml}$ to $25 \mathrm{mg} / \mathrm{ml}$ concentration of PAA $(\mathrm{P}<0.01)$. The $\mathrm{EC}_{50}$ value of PAA affecting $50 \%$ of L-929 cells was determined as $1.8 \mathrm{mg} / \mathrm{ml}$ (Figure $3 \mathrm{~B}$ ).

\section{Determination of the apoptotic effects of PAA on MCF-7 and L-929 cells by DAPI}

As a result of nuclear staining with DAPI, the nucleus of the MCF-7 cells (Control) was equal in volume and cell division was observed. No apoptotic body was detected (Figure 4A). Apoptotic body was significantly increased in MCF-7 cells treated with $10 \mathrm{mg} / \mathrm{ml}$ PAA compared to control $(\mathrm{P}<0.05)$. On the other hand, the apoptotic body showed an insignificant increase in cells treated with $4 \mathrm{mg} / \mathrm{ml}$ PAA compared to the control (Figure 4B). The apoptotic body was observed in L-929 control cells (Figure 4A). It was determined that apoptotic body was insignificantly increased in PAA treated L-929 cells compared to control (Figure 4B).

\section{Discussion}

The results of this study revealed that PAA dose-dependent cytotoxic properties, and induce apoptosis pathway in MCF-7 cells. PAA is a weak polyelectrolyte and has been used in several biomedical applications such as immunological studies, drug delivery, and enzyme immobilization. Many studies have revealed that PAA as a polymer is used in combination with other materials in various biomaterials $(26,27,17)$.

Cells lose their specialized structures and contact surfaces with other cells when their morphology changes. They shrink by losing water. It is observed that the cytoplasm is condensed, and the organelles converge. Membrane integrity is preserved. Organelles are generally intact. Mitochondria generally retain their normal structure. The most important morphological changes are observed in the nucleus (28). In our study, we observed that morphological deformation occurred in MCF-7 and L-929 cells treated with high concentrations of PAA. The cells shrunk, lost their surface extension, became rounded, and the surface coverage of the cells decreased. Therefore PAA as a polymer should be used in low concentrations to prevent deformation on healthy cells such as L-929.

Cell viability is determined using trypan blue dye. In a study, the PAA nanoparticles were tested for viability by using trypan blue staining. Researchers, staining HHL5, HepG2 ve 3T3-L1 cells with Trypan Blue after treatment showed that nanoparti- 


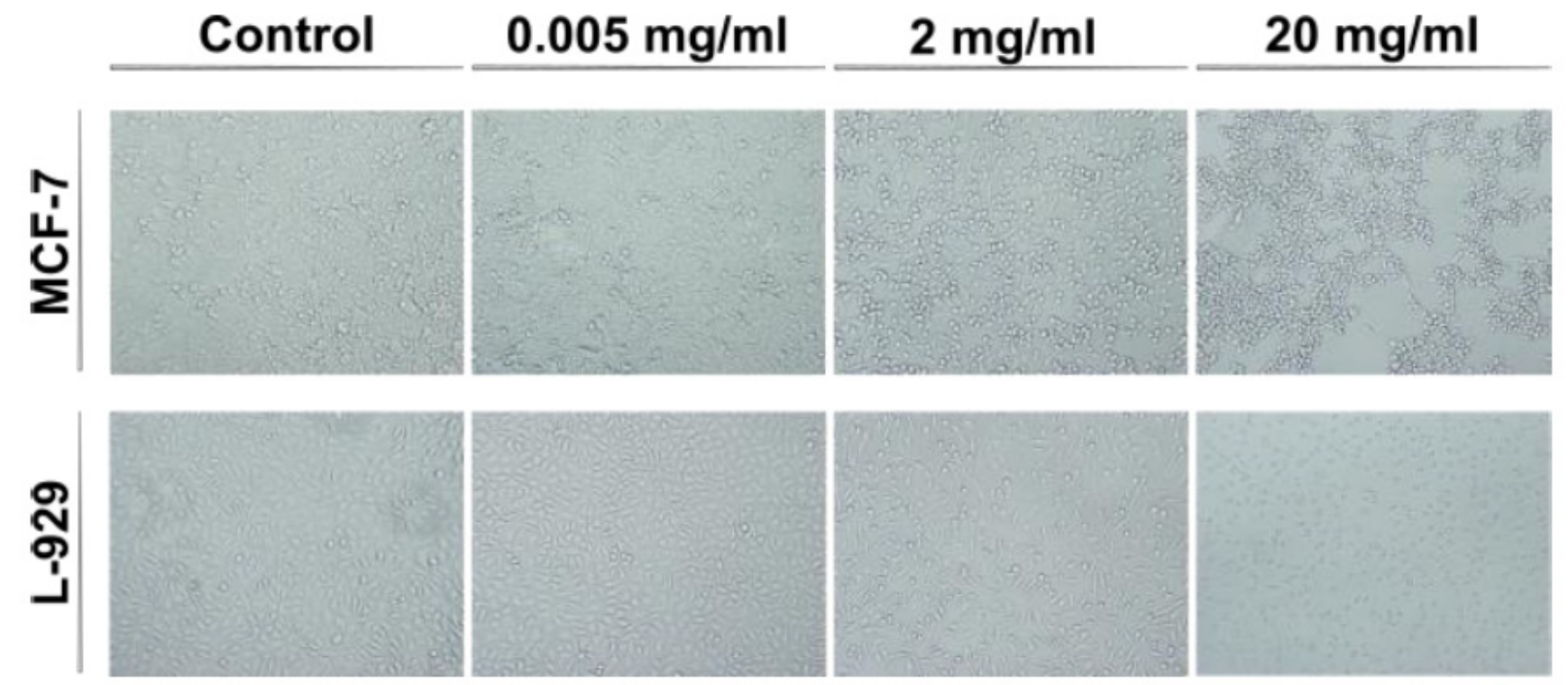

Figure 1. Phase-contrast microscope (x20) images of MCF-7 and L-929 cells treated with polyacrylic acid (PAA) at $0.005 \mathrm{mg} / \mathrm{ml}, 2 \mathrm{mg} / \mathrm{ml}$, and $20 \mathrm{mg} / \mathrm{ml}$ of concentrations for 24 hours.

A

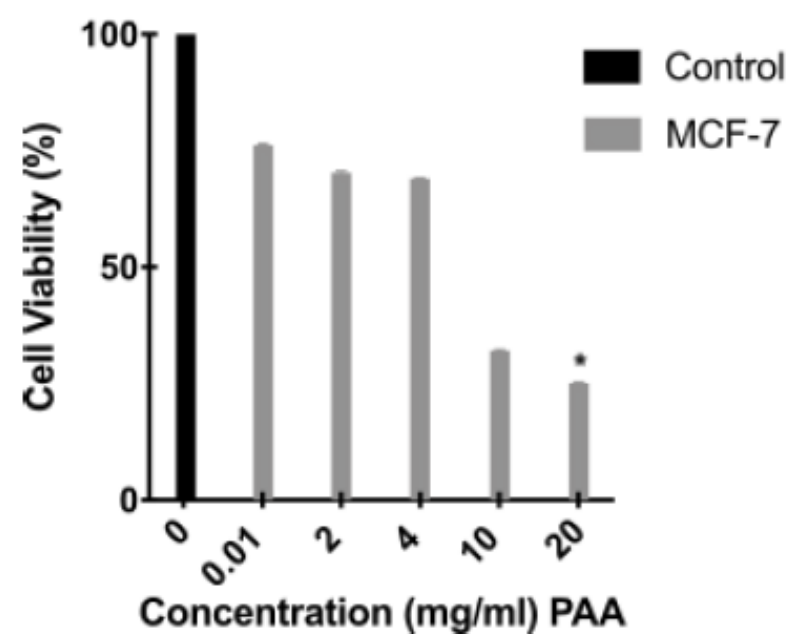

B

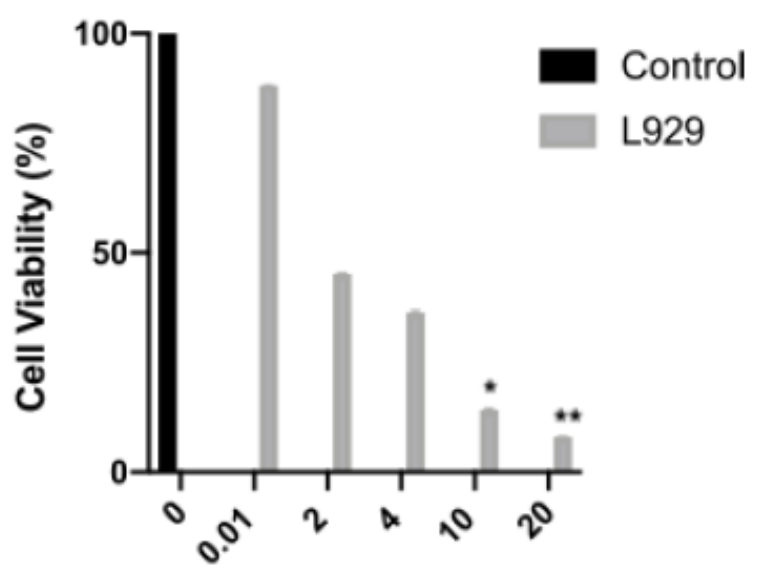

Concentration $(\mathrm{mg} / \mathrm{ml})$ PAA

Figure 2. The graph showing cell viability (\%) in MCF-7 (A) and L-929 (B) cells against concentrations of polyacrylic acid (PAA) for 24 hours. The values are shown as the mean \pm standard error of the mean. Compared to control groups, ${ }^{\star} \mathrm{P}<0.05,{ }^{*} \mathrm{P}<0.01$. 


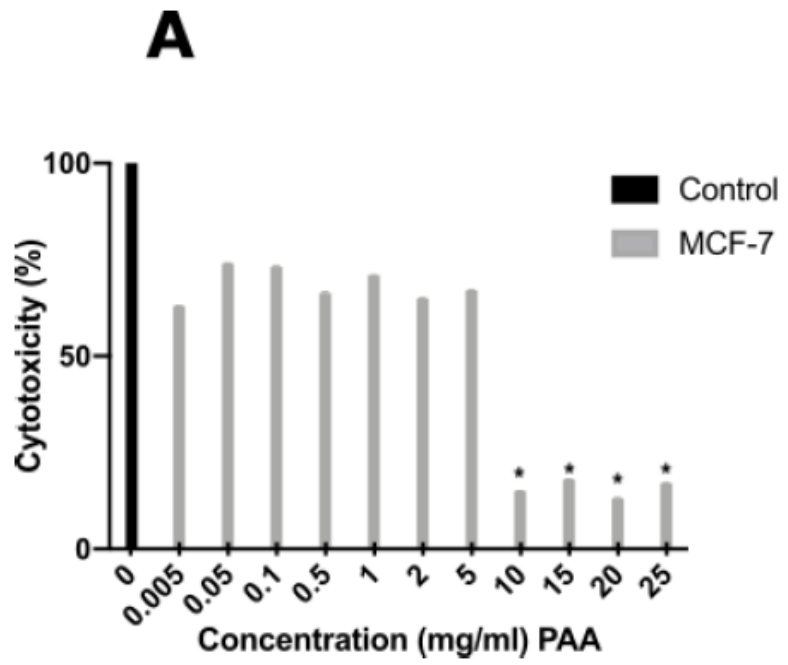

B

igure 3. The graph showing cytotoxicity (\%) in MCF-7 (A) and L-929 (B) cells against concentrations of polyacrylic acid (PAA) for 24 hours. The values are shown as the mean \pm standard error of the mean. Compared to control groups, ${ }^{\star} \mathrm{P}<0.05,{ }^{\star \star} \mathrm{P}<0.01$.

A

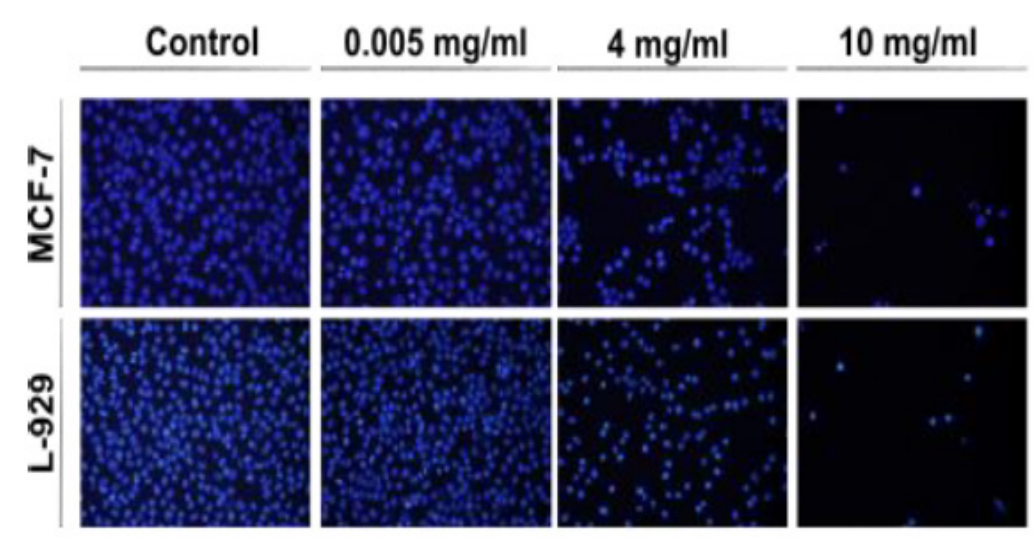

B

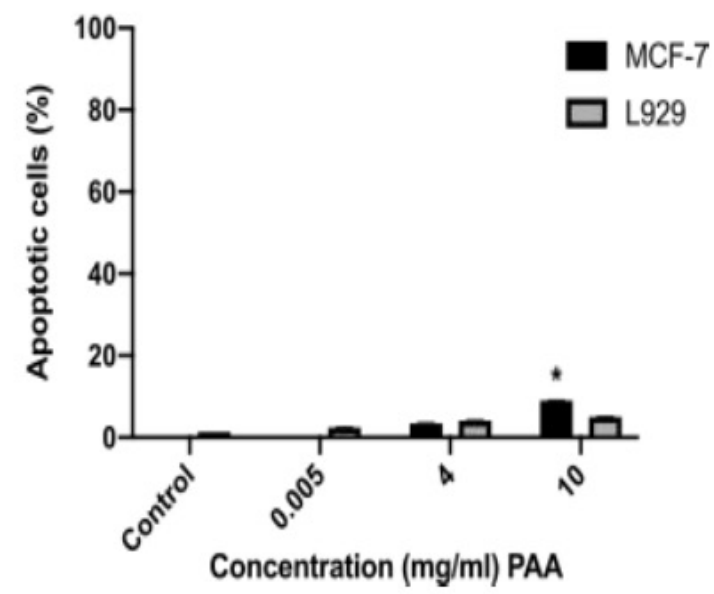

Figure 4. Fluorescent microscope (x40) images of MCF-7 and L-929 cells treated with polyacrylic acid (PAA) at $0.005 \mathrm{mg} / \mathrm{ml}, 4 \mathrm{mg} / \mathrm{ml}$, and 10 $\mathrm{mg} / \mathrm{ml}$ concentrations for 24 hours (A). The graph showing apoptotic cells (\%) in MCF-7 and L-929 cells against concentrations of polyacrylic acid (PAA) for 24 hours (B). The values are shown as the mean \pm standard error of the mean. Compared to control groups, ${ }^{\star} \mathrm{P}<0.05$.

cles no caused cytotoxity in cell viability (29). In another study, cell viability was determined by detecting plasma membrane permeability with trypan blue dye (30). In our study, decreased cell viability due to the increasing concentration of PAA in both cell lines showed the importance of applying PAA at opti- mal doses in cancer and healthy cells.

MTT assay is often used to evaluate the in vitro cytotoxicity of chemical agents (31). In a study, the cell toxicity of the PAA nanogel was determined by MTT and reported no cytotoxicity to A549 cells compared to the control and MTT assay 
proved their potential for biomedical application (32). In polymer-treated cells, the mitochondrial substrate converts MTT into formazan crystals and intracellular damage may not be observed. This metabolic activity of cells is a convenient method for assessing cell cytotoxicity (33). In another study reported that cytotoxicity of PAA was determined using MTT and 0-300 $\mu \mathrm{g} / \mathrm{ml}$ dose depended did not indicate toxic effects on L929 and J774 cells (7). In this study, the toxic effect of high doses of PAA in L-929 cells was demonstrated. In addition, the dose of PAA affecting $50 \%$ of cancer cells is at much higher concentrations. According to our results, selected concentrations of polymers used according to the purpose of biomedical applications are important for healthy and cancer cells. Also, The toxicity results of PAA obtained by the MTT method were similar to the trypan blue staining results in MCF 7 and L-929 cells.

In apoptosis, significant morphological changes occur in the nucleus. Chromatin precipitates in different shapes and sizes by condensing near the nuclear membrane. Electron microscope examination reveals that chromatin is located on the inner surface of the nuclear membrane. It also shrinks like a cell in that nucleus and can sometimes split into several pieces surrounded by a membrane. Apoptotic bodies occur as apoptosis progresses (28). In the current study, MCF 7 and L-929 cells were stained with a DNA-specific dye DAPI and examined under a fluorescent microscope to better characterize the morphologically observed cell death. DAPI formed a fluorescent complex with double-stranded DNA. According to our results, while control cells showed healthy cell morphology, typical morphological features of apoptotic cell death were observed at high concentrations of PAA as chromatin condensation and formation of apoptotic bodies containing nuclear fragments. Apoptosis specific shrinkage occurred in the nucleus of the cells. In the studies of Di et al., the apoptotic effect of the PAA-nanoparticle was investigated with DAPI and it was reported that this nanoparticle activates the apoptosis pathway (26). The results of our study showed that PAA activates the apoptosis pathway in breast cancer cells. Accordingly, PAA may be used as a polymer in biomaterials for breast cancer. DAPI results showing pathological changes in the cell nucleus support the results of MTT and trypan blue staining methods.

\section{Conclusion}

Different concentrations of PAA have a dose-dependent cytotoxic effect on MCF-7 and L-929 cells. PAA in high concentrations may inhibit the proliferation of breast cancer cells. In addition, PAA may activate the apoptosis pathway in cells in a dose-dependent manner. Therefore, PAA may be considered as a polymer agent in biomaterials to be used in breast cancer. In vitro and in vivo studies are needed to confirm the efficacy of PAA in breast cancer.

\section{Conflicts of interest/Competing interests:}

The authors declare that they have no conflict of interest.

\section{Acknowledgements}

The authors received no financial support for this work.

\section{References}

1. Kadajji VG, Betageri GV. Water soluble polymers for pharmaceutical applications. Polymers (Basel) 2011; 3(4): 1972-2009.

2. Popat SK, Asmita MS, Onkar BP, Arehalli SM, John ID. Podophyllotoxin-polyacrylic acid conjugate micelles: improved anticancer efficacy against multidrug-resistant breast cancer. J Egypt Natl Canc Inst 2020; 32(1): 42.

3. Dehbari N, Tavakoli J, Khatrao SS, Tang Y. In situ polymerized hyperbranched polymer reinforced poly(acrylic acid) hydrogels. Mater Chem Front 2017; 1(10): 1995- 2004.

4. Morton SW, Shah NJ, Quadir MA, Deng ZJ, Poon Z, Hammond PT. Osteotropic therapy via targeted layer-by-layer nanoparticles. Adv Healthc Mater 2014; 3(6): 867-875.

5. Yang, JM, Huang, MJ, Yeh, TS. Preparation of poly (acrylic acid) modified polyurethane membrane for biomaterial by UV radiation without degassing. J. Biomed. Mater. Res 1999; 45(2): 133-139.

6. de Gigglio E, Cafaga D, Ricci MA, Sabbatini L, Cometa S, Ferretti C, Mattioli-Belmonte M. Biocompatibility of poly(acrylic acid) thin coatings electro-synthesized onto TiAlV-based implants. J. Bioact Compat Polym 2010; 25(4): 374-391.

7. Topuzogullari M, Cakir-Koc R, Dincer-Isoglu S, Bagirova M, Akdeste Z, Elcicek S, Oztel ON, Yesilkir-Baydar S, Canim-Ates S, Allahverdiyev AM. Conjugation, characterization and toxicity of lipophosphoglycan-polyacrylic acid conjugate for vaccination against leishmaniasis. Journal of Biomedical Science 2013; 20(35): 1-8.

8. Petrov RV, Kabanov VA, Khaitov RM, Mustafaev MI, Norimov A. Effect of heparin on the immunogenicity of electrostatic covalent albumin complexes with synthetic polyions. Immunogenicity of the triple covalent complex polyelectrolyte-protein-heparin. Mol Gen Mikrobiol Virusol 1986; 30-35.

9. Yuk $\mathrm{SH}$, Cho $\mathrm{SH}$, Lee HB. pH-sensitive drug delivery system using OW emulsion. J Control Release 1995; 37: 69-74.

10. Gao XY, He CL, Xiao CS, Zhuang XL, Chen XS. Biodegradable $\mathrm{pH}$-responsive polyacrylic acid derivative hydrogels with tunable swelling behavior for oral delivery of insulin. Polymer 2013; 54(7): 1786-1793.

11. Bianchi D, Golini P, Bortolo R, Cesti P. Immobilization of penicillin $G$ acylase on aminoalkylated polyacrylic supports. Enzyme Microb Technol 1996; 18:5 92-596.

12. Hanafy NAN, El-Kemary M, Leporatti S. Reduction diameter of $\mathrm{CaCO} 3$ crystals by using poly acrylic acid might improve cellular uptake of encapsulated curcumin in breast cancer. Journal of Nanomedicine Research 2018; 7(4): 235-239.

13. Saberi J, Ansari M, Hoseinzadeh BE, Kordestani SS, Naghip SM. Chitosan-polyacrylic acid hybrid nanoparticles as novel tissue adhesive: Synthesis and characteriza- 
tion. Fibers and Polymers 2018; 19: 2458-2464.

14. Urkmez AS, Bayir E, Bilgi E, Ozen MÖ. Biocompatible polymeric coatings do not inherently reduce the cytotoxicity of iron oxide nanoparticles. Turk J Biol 2017; 41: 322-332.

15. Gupta S, Vyas SP. Carbopol/chitosan based $\mathrm{pH}$ triggered in situ gelling system for ocular delivery of timolol maleate. Sci Pharm 2010; 78: 959-976.

16. Wang H, Dai T, Zhou S, Huang X, Li S, Sun K, Zhou G, Dou H. Self-assembly assisted fabrication of dextran-based nanohydrogels with reduction-cleavable junctions for applications as efficient drug delivery systems. Sci Rep 2017; 7: 40011.

17. Gu Y, Qiao X, Zhang J, Sun Y, Tao Y, Qiao S. Effects of surface modification of upconversion nanoparticles on cellular uptake and cytotoxicit. Functionalized Upconversion Nanoparticles for Cancer Imaging and Therapy 2016; 51-64.

18. Vakili MR, Mohammed-Saeid W, Aljasser A, Hopwood-Raja J, Ahvazi B, Hrynets Y, Betti M, Lavasanifar A. Development of mucoadhesive hydrogels based on polyacrylic acid grafted cellulose nanocrystals for local cisplatin delivery. Carbohydr Polym 2021; 1:255: 117332.

19. Kumbhar PS, Sakate AM, Patil OB, Manjappa AS, Disouza JI. Podophyllotoxin-polyacrylic acid conjugate micelles: improved anticancer efficacy against multidrug-resistant breast cancer. Journal of the Egyptian National Cancer Institute 2020; 32: 42-50.

20. Wallin RF. Testing for cytotoxicity is a good first step toward ensuring the biocompatibility of a medical device. A Practical Guide to ISO 10993-5:Cytotoxicity 1998.

21. Cannella V, Altomare R, Leonardi V, Russotto L, Bella SD, Mira F, and Guercio A. In vitro biocompatibility evaluation of nine dermal fillers on L929 cell line. BioMed Research International 2020; 1-6.

22. Elmore S. Apoptosis: a review of programmed cell death. Toxicol Pathol 2007; 35(4): 495-516.

23. Chazotte. Labeling nuclear DNA using DAPI. Cold Spring Harb Protoc 2011; 80-82.

24. Strober W. Trypan blue exclusion test of cell viability. Curr Protoc Immunol 2019; 1-3.

25. Kumar P, Nagarajan A, Uchil PD. Analysis of cell viability by the MTT assay. Cold Spring Harb Protoc 2018; 469-472.

26. Di W, Zi-Qiang Z, Hai-Xiao T, Zhi-En S, Jian K, Qiang L, Jun Q. Research paper efficacy-shaping nanomedicine by loading calcium peroxide into tumor microenvironment-responsive nanoparticles for the antitumor therapy of prostate cancer. Theranostics 2020; 10(21): 9808-9829.

27. Nunez NO, Cusso F, Cantelar E, Martin-Gracia B, de la Fuente JM, Corral A, Balcerzyk M, Ocana M. Bimodal Nddoped LuVO4 nanoprobes functionalized with polyacrilic acid for X-Ray computed tomography and NIR luminescent 1maging. Nanomaterials (Basel) 2020; 10(1): 149.

28. Bozic B, Rozman B. Apoptosis and autoimmunity. EJIFCC 2006; 17(3): 69-74.
29. Wang Q, Bao Y, Zhang X, Coxon PR, Jayasooriya UA, and Chao Y. Uptake and toxicity studies of poly-acrylic acid functionalized silicon nanoparticles in cultured mammalian cells. Adv. Healthcare Mater. 2012, 1: 189-198.

30. Iwona Zwolak. Comparison of three different cell viability assays for evaluation of vanadyl sulphate cytoto xicity in a Chinese hamster ovary K1 cell line. Toxicology and Industrial Health 2014; 32(6): 1013-1025.

31. Ryu M, Matsumura R, Quan G, Furuta T. Comparison of the cytotoxicity of high-level disinfectants by the MTT assay and direct contact assay. Biocontrol Sci 2013; 18(4): 221-5.

32. Ghorbaniazar P, Sepehrianazar A, Eskandani M, Nabi-Meibodi M, Kouhsoltani M, Hamishehkar H. Preparation of poly acrylic acid-poly acrylamide composite nanogels by radiation technique. Pharm Bull 2015; 5(2): 269-275.

33. Dorkoosh FA, Setyaningsih D, Borchard G, Rafiee-Tehrani $\mathrm{M}$, Verhoef JC, Junginger HE. Effects of superporous hydrogels on paracellular drug permeability and cytotoxicity studies in Caco-2 cell monolayers. International Journal of Pharmaceutics 2002; 241: 35-45. 